\title{
The effects of minimum wages on youth employment and income
}

\section{Minimum wages reduce entry-level jobs, training, and lifetime income}

Keywords: minimum wages, youth employment, entry-level jobs, work experience, on-the-job training

\section{ELEVATOR PITCH}

Policymakers often propose a minimum wage as a means of raising incomes and lifting workers out of poverty. However, improvements in some young workers' incomes as a result of a minimum wage come at a cost to others. Minimum wages reduce employment opportunities for youths and create unemployment. Workers miss out on on-the-job training opportunities that would have been paid for by reduced wages upfront but would have resulted in higher wages later. Youths who cannot find jobs must be supported by their families or by the social welfare system. Delayed entry into the labor market reduces the lifetime income stream of young unskilled workers.

\section{KEY FINDINGS}

\section{Pros}

๑ Imposing a minimum wage may increase the income of working youths if their hours of work are not reduced in response to the minimum wage.

( Minimum wages may increase the aggregate income of youths if the gains for those who work exceed the losses for those who cannot find work.

- In the rare instance where an employer has market power over wages, imposing a minimum wage could boost employment among youths.

๑ Some studies argue that the negative empirical results found in other studies of minimum wage imposition are a result of methodological flaws.

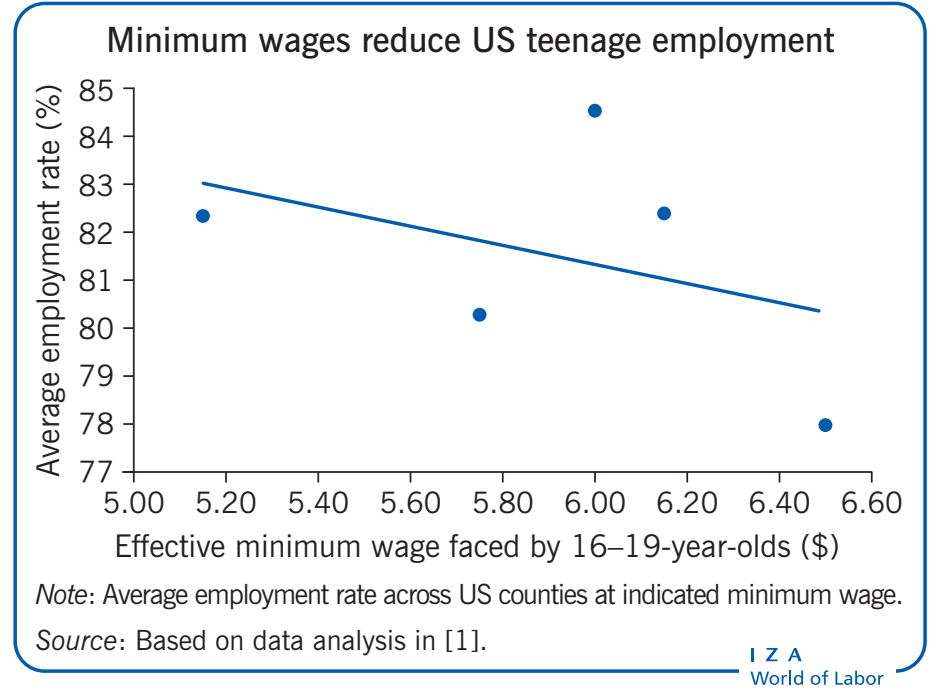

\section{Cons}

- In a competitive labor market for young unskilled workers, minimum wages reduce youth employment.

- A minimum wage reduces lifetime income by delaying the labor market entry of youths who fail to obtain jobs at the higher (minimum) wage.

- Minimum wages create youth unemployment by increasing the number of job seekers and reducing the number of jobs available.

- Minimum wages reduce on-the-job training opportunities and thus youths' lifetime income.

\section{AUTHOR'S MAIN MESSAGE}

Evidence shows that minimum wages reduce employment and create unemployment among young unskilled workers. While some youths will benefit from higher current earnings, others will not find work, delaying labor market entry and reducing lifetime incomes. Without a "sub-minimum training wage" for entry-level workers, employers may limit on-the-job training, which will also reduce lifetime incomes. Instead of a minimum wage, policymakers should use less distortionary means to support young unskilled workers, such as cash or in-kind assistance. 


\section{MOTIVATION}

Policymakers often propose minimum wages as a way of raising workers' incomes and thus lifting them out of poverty. However, there is a substantial body of research that shows negative effects of minimum wages on employment. Because youths are often the largest beneficiaries of minimum wages (53\% in the US in 2014, based on Bureau of Labor Statistics data), policymakers need to know how minimum wages affect youth employment before implementing such policies.

When a minimum wage is imposed or raised, the hourly wage of young workers rises. However, employers respond to the increased hourly labor cost for young workers by reducing their hours of work, cutting jobs, or both. In addition, because more youths seek jobs at the higher wage, a gap is created between the number of jobs desired and those available. This gap is youth unemployment. Young adults without a job then impose a financial burden on their families or on the social welfare system, while delayed entry into the labor force reduces youths' lifetime earnings. In addition, employers may reduce or eliminate on-the-job training opportunities that they had previously funded through low entry-level/training wages, thereby also contributing to lower human capital accumulation and lower lifetime incomes.

\section{DISCUSSION OF PROS AND CONS}

\section{Minimum wages reduce youth employment and create unemployment}

\section{Standard economic theory}

Standard economic theory predicts that imposing a minimum wage will reduce employment and increase unemployment. Figure 1 shows a supply and demand diagram of a competitive market for young unskilled workers. To make the example

Figure 1. Imposing a minimum wage lowers employment and raises unemployment

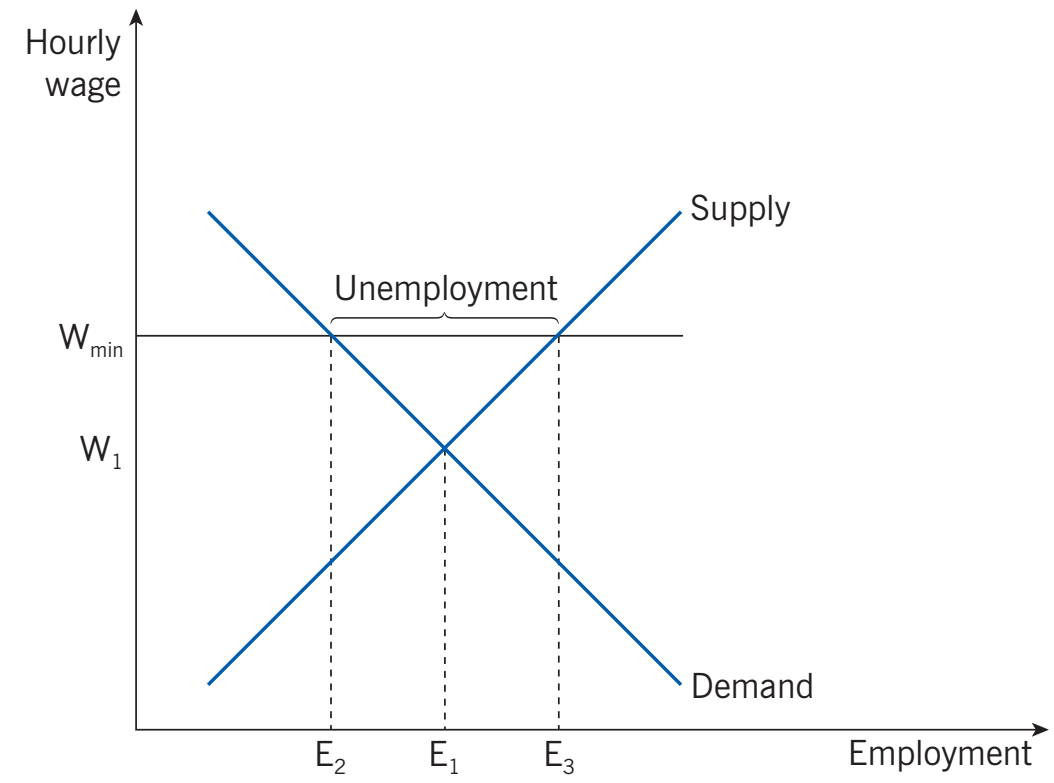

Source: Author's illustration. 
more concrete, assume that this is the market for grocery baggers (used as a typical example for unskilled young workers-the types of workers most affected by minimum wages). The hourly wage for such workers is measured on the vertical axis, and their employment is measured on the horizontal axis. Employment can be thought of as either the total number of bagger hours hired or the number of bagger jobs available, because grocery store employers may adjust employment by changing the number of hours worked by current baggers or by changing the number of baggers hired. The demand for baggers slopes downward, indicating that grocery stores demand fewer hours of bagging/fewer total baggers as the hourly wage rises. To some extent, grocery stores can deal with a reduction in grocery baggers employed by asking customers to bag their own groceries or by installing self-checkout lanes in their stores. The supply of workers is upward-sloping, indicating that higher hourly wages attract more young people to grocery-bagging jobs and encourage current grocery baggers to work more hours. The intersection of the supply and demand curve gives the wage $\left(W_{1}\right)$ and employment level $\left(E_{1}\right)$ of grocery baggers determined by the market without government intervention.

Now, imagine that the government imposes a minimum wage on this market in order to improve grocery baggers' earnings. To be effective, this minimum wage $\left(\mathrm{W}_{\min }\right.$, the horizontal line in Figure 1) must be positioned above the current wage of $W_{1}$. Because imposition of the minimum wage raises the cost per grocery bagger, grocery stores will cut back on hiring grocery baggers/the number of hours of bagging. Thus, only $E_{2}$ grocery-bagging jobs are now available, down from the previous level of $E_{1}$.

In addition to reducing employment, the higher wage under the minimum wage legislation leads to more unemployment, defined as the number of workers seeking a job at a given wage minus the number of jobs available. At the higher (minimum) wage, grocery stores cut back on baggers, while more workers queue up for bagging jobs at the higher wage. Unemployment is shown in Figure 1 as the horizontal distance between the supply and demand curves at the minimum wage.

\section{Empirical evidence of the impact of minimum wages on youth unemployment}

There is a substantial body of empirical evidence on the effects of a minimum wage on youth employment. Most of the studies have found negative effects on youth employment [2]. A 1992 study of youth employment in the US found that a 10\% increase in the minimum wage led to a $1-2 \%$ decline in the employment of teenagers and a 1.5-2\% decline in the employment of young adults [3]. A 2014 study of youth employment in the US showed a decline of $1.5 \%$ for teenagers [2]. Thus, the estimated negative effect of minimum wages on employment in the US has been fairly consistent over time. However, these estimates are national averages, which obscure regional effects. A $10 \%$ increase in the minimum wage has been found to reduce regional employment by as much as $7 \%$ [4]. One study that looked at teenage unemployment rates in the US instead of employment found that minimum wages indeed increase teen unemployment rates, as the standard economic model predicts [5].

A study of the effects of increasing the minimum wage in the EU also found statistically significant negative effects on employment of teenagers (those aged 15-19) and young adults (those aged 20-24), with larger effects for teenagers, over the period 1996- 
2011 [6]. Furthermore, a $10 \%$ increase in the minimum wage led, on average, to a 7.4-10.5\% decrease in employment of teenagers and a $2.9-3.8 \%$ decrease for young adults. These are larger effects for both groups than those estimated for youth in the US.

A study of the effects of minimum wages across OECD countries also shows negative effects of minimum wages on the employment of youth, but the negative effects vary considerably across countries [7]. In particular, the effects are larger the more restrictive a country's labor standards and the higher its labor union coverage. The effects are weaker in countries with strong employment protection laws and active labor market policies that aid the unemployed in finding jobs. The strongest minimum wage effects are found in countries with very little regulation of labor markets.

All of these studies found negative effects that are consistent with the competitive model of the youth labor market described above. However, some studies have found no evidence that minimum wages reduce employment. Most of these studies have argued that the negative empirical results found in other studies are a result of methodological flaws [8], [9]. However, these studies claiming methodological flaws often have focused on narrow groups of workers or case studies. More recently, studies claiming methodological problems have argued that when spatial correlation is taken into account, the negative effects of minimum wages disappear [10], [11].

Spatial correlation is the idea that employment is related across measured units. For example, employment measured in one county may be positively related to employment measured in a neighboring county due to an underlying geographic feature such as a mountain that can be mined for coal or a river that can be used for transporting goods. In these cases, the mining or transportation industry will operate and employ workers across county boundaries. If the industries are doing well, employment will be high in both counties, all else being equal. Alternatively, if the industries are doing poorly, employment will be low in both counties. Another possibility is that employment in one county is positively related to employment in a neighboring county due to similar labor force or demographic characteristics in both counties. Labor markets do not necessarily follow political boundaries.

The studies that attempt to account for spatial correlation have used indirect and informal methods to do so. One technique adds state-specific linear trends or census division-time period interactions to the standard panel data analyses. Another technique examines paired border counties. However, one study that used similar informal techniques to deal with spatial correlation found the opposite result, that minimum wages do reduce teen employment [2].

Formal econometric models and techniques that account for spatial correlation also have been applied to study minimum wages in the US, finding that minimum wages have negative effects on teenage employment. Moreover, formally accounting for spatial correlation increases the magnitude of the estimated effects.

One study using US county-level data for 2000 and formal, direct spatial econometric techniques shows that a $10 \%$ increase in the effective minimum wage (the maximum of the US federal and state minimum wages) is associated with a $3.2 \%$ decrease in youth employment [1]. Research using state-year-level data for 1990-2004 found that 
a $10 \%$ increase in the effective minimum wage (accounting for inflation) resulted in a $2.1 \%$ decrease in youth employment, a larger effect than found in the same data when spatial dependence is not accounted for [12].

\section{Minimum wages may increase young workers' incomes}

Minimum wages are intended to improve the earnings of unskilled workers. But do they? Figure 2 builds on Figure 1 to show the aggregate earnings of grocery baggers before the imposition of a minimum wage (area 1 , which is $W_{1}$ times $E_{1}$ ) and after it (area 2, which is $W_{\min }$ times $E_{2}$ ). If area 2 is greater than area 1 , then the aggregate earnings of grocery baggers will increase as a result of the minimum wage. This depends on the elasticity of the demand for grocery baggers-that is, the responsiveness of the quantity of grocery baggers demanded by grocery store employers to a wage increase. If grocery stores are not very responsive to wage increases, they do not reduce their employment much following imposition of a minimum wage (inelastic demand), and the aggregate earnings of grocery baggers will increase. However, if grocery stores are very responsive to wage increases and thus reduce employment considerably in response to a minimum wage (elastic demand), then the aggregate earnings of grocery baggers will decrease as a result of the minimum wage. Depending on how acceptable substitutes for grocery baggers (self-bagging, self-checkout lanes) are to customers, the demand for grocery baggers may be more or less elastic.

Although there is not much empirical research on the effects of a minimum wage on aggregate earnings, one study did find that the imposition of a minimum wage raised the earnings of low-wage workers by 5-10\% [9]. It is important to note, however, that the incomes that may rise are those of youths who have jobs. Youths who are unable

Figure 2. The effects of minimum wages on aggregate earnings depend on how responsive the demand for labor is to a wage increase

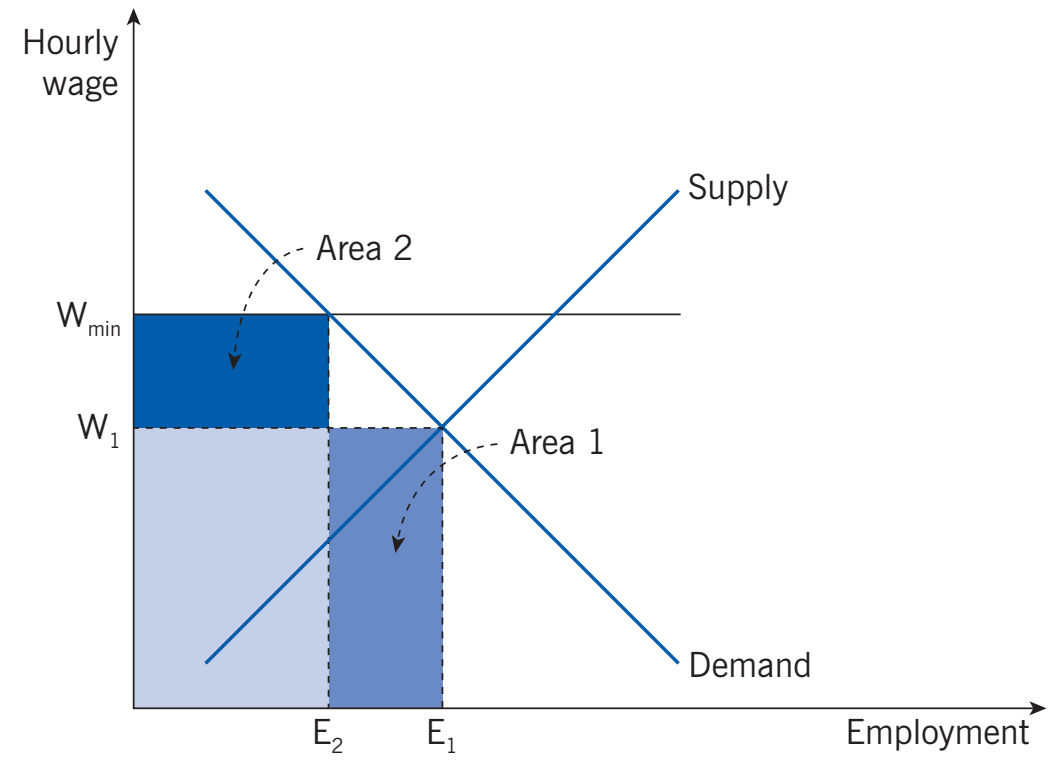

Note: If area 2 is greater than area 1 , then the aggregate earnings will increase as a result of the minimum wage. Source: Author's illustration. 
to find employment as a result of the minimum wage will delay their entry into the labor force, resulting in a decline in their lifetime income.

\section{Minimum wages reduce on-the-job training opportunities and, thus, lifetime income}

Coming back to the example of grocery store baggers who may receive some on-thejob training at the start of their employment, perhaps by watching training videos and shadowing senior grocery store employees, Figure 3 shows how the presence of onthe-job training changes the relationship between age and earnings. The horizontal line (measuring age) at $W_{1}$ shows how a hypothetical age-earnings profile might look without on-the-job training. Earnings (measured on the vertical axis) would remain constant over time because there would be no increase in work productivity over time. If grocery stores offered on-the-job training, they would also offer a lower initial training wage, $W_{T}$, to account for lost work productivity while training. After training, however, grocery stores would offer trained grocery baggers a higher wage, $\mathrm{W}_{2}$, to reward their now-greater productivity. Thus, the earnings of a grocery bagger receiving on-the-job training would be lower at first than the earnings of baggers not receiving training but would later surpass their earnings.

It is possible that the productivity of a worker could increase over time without formal on-the-job training. In that case, the age-earnings profile of the worker who is not formally trained would be slightly upward-sloping rather than horizontal. In addition, the worker who undergoes formal training is probably gaining informal training as well, also making that worker's age-earning profile upward-sloping and perhaps more continuous. However, the slope of the formally trained worker's age-earning profile will exceed that of the informally trained worker. That means that the earnings of the bagger receiving formal training, while still lower at first, would eventually surpass the earnings of the bagger who received only informal training.

How might the imposition of a minimum wage affect whether grocery store employers offer on-the-job training? If the minimum wage were set at $W_{1}$ in Figure 3 , for example,

Figure 3. On-the-job training changes the relationship between age and earnings

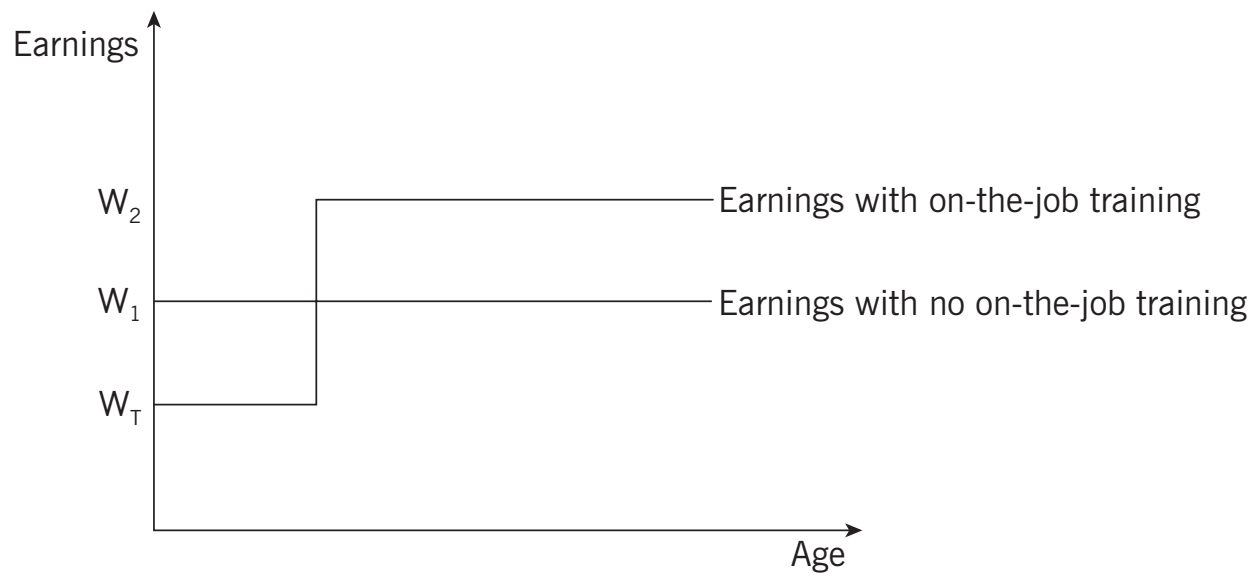

Source: Author's illustration. 
grocery store employers would be unable to offer on-the-job training to their grocery bagger employees. Workers would find themselves on the horizontal age-earnings profile at $W_{1}$ and would thus earn less income over a lifetime than they might have had they been able to receive on-the-job training.

Recognizing this relationship, some US states and some EU member countries have allowed employers to offer sub-minimum or training wages for youths in order to encourage employers to hire and train young, unskilled workers. Separate minimum wages for the least skilled young workers are common in Nordic labor markets, where minimum wages are typically stipulated in binding collective labor agreements. The empirical evidence that exists for the US suggests that such exemptions from the minimum wage may have reduced the negative effects of the minimum wage on youth employment or may even have had positive effects on youth employment [3], [13]. Such exemptions to the state-level minimum wage have included young workers (under age 18), workers in school, workers engaged in training, workers in certain industries and occupations, and workers in very small companies [13]. However, these exemptions have not been part of a broader national policy but have varied by state.

Evidence from OECD countries suggests that provisions for a sub-minimum wage for youths (allowing them to be paid less than the statutory minimum wage for adult workers) reduce the magnitude of the negative effects on youth employment [7].

\section{How minimum wages may increase employment}

The standard economic model of the labor market for unskilled youth assumes that this market is competitive. That is, neither an individual employer nor an individual employee can choose the market wage. However, if the market for young unskilled workers is monopsonistic, meaning that the firm has market power and thus can affect the wage, then increasing the minimum wage would increase youth employment [9].

Suppose, for example, that a grocery store is the only employer of youth on an island, so the employer has complete market power over the wage. Figure 4 shows what such a labor market might look like and also how employment can increase as a result of a minimum wage imposed on such a market. The demand curve slopes downward and shows how much additional revenue each additional grocery bagger brings in to the grocery store. The supply curve slopes upward, as before, because a higher wage attracts more young people to grocery-bagging jobs and encourages current grocery baggers to work more hours. However, there is an additional curve on this graph that was not in the previous graphs. It is the marginal expense curve, which shows how much it will cost the grocery store to hire an additional grocery bagger. Because each worker hired increases the wage paid, and this wage must be paid to all previous workers, not just the last, the additional expense of hiring a new worker is greater than simply the wage paid to the last worker. Therefore, the marginal expense curve lies above the supply curve.

Without a minimum wage, the grocery store employer will choose to hire $L_{1}$, the level of employment where the demand curve intersects the marginal expense curve. This is the point at which the additional revenue brought in by an additional grocery bagger just equals the marginal cost of hiring that worker. The wage paid to all grocery 
Figure 4. Minimum wages increase employment under monopsony conditions

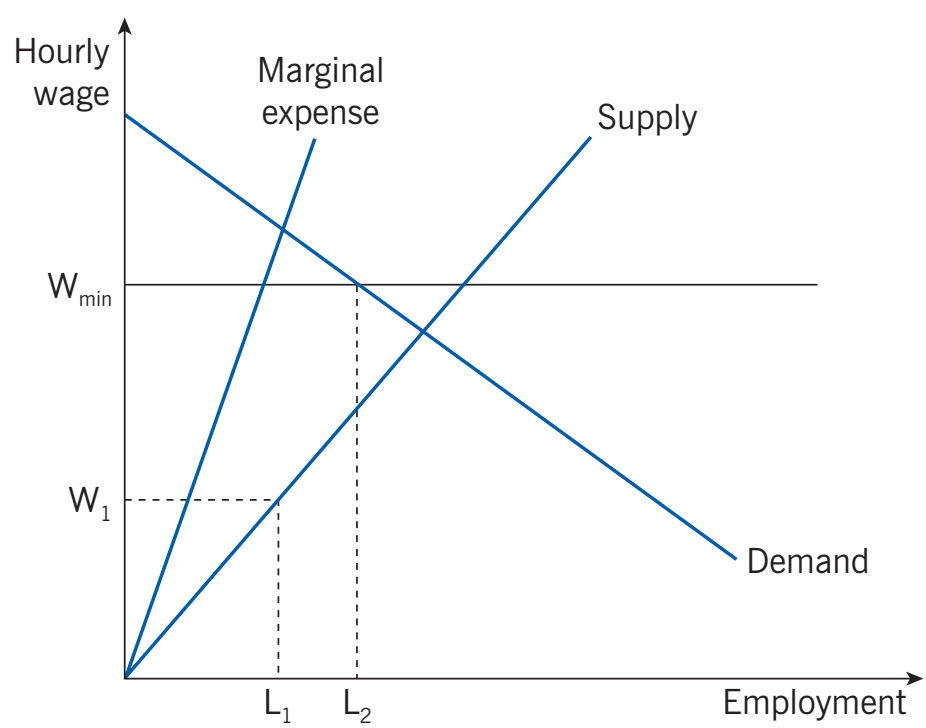

Source: Author's illustration.

baggers is $W_{1}$. This is lower than the wage that would exist in a competitive market (the point at which demand and supply intersect). Now, suppose that a minimum wage, $W_{\min }$, is imposed that is above both $W_{1}$ and the wage in a competitive market. At this higher wage, the grocery store will hire $L_{2}$ grocery baggers, which is higher than $\mathrm{L}_{1}$. Thus, in the case of a monopsonistic labor market, imposition of a minimum wage will increase the employment of grocery baggers. Note, however, that because $W_{\min }$ is set above the competitive wage, it also will increase unemployment. Unemployment of grocery baggers created by the minimum wage is the difference between the supply and demand curves at $W_{\min }$. Thus, even when imposition of a minimum wage increases employment, it still results in unemployment of grocery baggers.

It is important to note that the story of rising employment and the creation of unemployment in a monopsonistic labor market as a result of the imposition of a minimum wage may still hold if there are a few, but not many, grocery stores. As the number of grocery stores increases, each will have less market power. Eventually, in the case of many grocery stores, an individual grocery store will have no market power. In the real world, there are many "grocery stores," meaning that there are many opportunities for youth employment. Thus, in the real world, a monopsonistic labor market for unskilled youth seems unlikely.

\section{LIMITATIONS AND GAPS}

The economic theory describing the labor market for unskilled youth has been called into question numerous times in recent decades. Is the labor market for unskilled youth a competitive one or monopsonistic? The bulk of the empirical evidence is consistent with a competitive market in that the imposition of a minimum wage (or an increase in the minimum wage) reduces youth employment. However, there are 
studies that show no employment effects of minimum wages and an occasional study that shows a positive effect. Findings of no effect are consistent with a minimum wage that is below the market wage and therefore is ineffective. Studies that show positive effects of minimum wages on youth employment are consistent with the monopsony story. However, it is difficult to conceive of a real-world case in which young people face only one or just a few potential employers, given the large number of grocery stores, fast-food restaurants, and other unskilled work opportunities in most areas. Thus, even though much recent empirical work has focused on methodological issues, a potentially profitable area of research may be in refining the theory applicable to youth labor markets.

\section{SUMMARY AND POLICY ADVICE}

The bulk of the empirical evidence supports the prediction of the standard economic model that minimum wages reduce employment and create unemployment among youths. It also shows that reducing or eliminating the minimum wage for young unskilled workers reduces these negative effects. Thus, minimum wages may not be the best way to improve the labor market situation of unskilled youth. While some working youth will benefit from increased current earnings, others will suffer from reduced opportunities and lower lifetime earnings. Delays in labor market entry and work experience will reduce lifetime incomes for youths who are unable to find employment because of the minimum wage. In addition, if the minimum wage comes without a sub-minimum or training wage, employers may reduce the on-the-job training opportunities they offer, thereby further reducing young workers' lifetime incomes.

Rather than using a minimum wage to increase youths' current incomes, policymakers should consider policies that improve the labor market opportunities of youths but do not increase the cost to employers of hiring young workers. Policies that would achieve both goals include providing cash welfare payments to youth if their earned income falls below some guaranteed level and providing in-kind support, such as food or housing assistance. Such policies create their own distortions (for example, causing some benefit recipients to choose not to work) but would not reduce the total number of jobs available or create unemployment.

\section{Acknowledgments}

The author thanks two anonymous referees and the IZA World of Labor editors for helpful suggestions on earlier drafts. The author also thanks Yuanshan Cheng and Patrick Payne for their research assistance.

\section{Competing interests}

The IZA World of Labor project is committed to the IZA Guiding Principles of Research Integrity. The author declares to have observed these principles.

(c) Charlene Marie Kalenkoski 


\section{REFERENCES}

\section{Further reading}

Anselin, L., and D. Arribas-Bel. "Spatial fixed effects and spatial dependence in a single cross section." Papers in Regional Science 92:1 (2013): 3-17.

Ehrenberg, R. G., R. S. Smith, and R. P. Chaykowski. Modern Labor Economics: Theory and Public Policy. 12th edition. Upper Saddle River, NJ: Pearson Education, 2015.

\section{Key references}

[1] Kalenkoski, C. M., and D. J. Lacombe. "Effects of minimum wages on youth employment: The importance of accounting for spatial correlation.” Journal of Labor Research 29:4 (2008): 303-317.

[2] Neumark, D., M. I. Salas, and W. Wascher. "Revisiting the minimum wage-employment debate: Throwing out the baby with the bathwater?" Industrial and Labor Relations Review 67:3 (2014): 608-648.

[3] Neumark, D., and W. Wascher. "Employment effects of minimum and subminimum wages: Panel data on state minimum wage laws." Industrial and Labor Relations Review 46:1 (1992): 55-81.

[4] Williams, N. "Regional effects of the minimum wage on teenage employment." Applied Economics 25:12 (1993): 1517-1528.

[5] Partridge, M. D., and J. S. Partridge. "Are teen unemployment rates influenced by state minimum wage laws?" Growth and Change 29:4 (1998): 359-382.

[6] Laporsek, S. "Minimum wage effects on youth employment in the European Union." Applied Economics Letters 20:14 (2013): 1288-1292.

[7] Neumark, D., and W. Wascher. "Minimum wages, labor market institutions, and youth employment: A cross-national analysis." Industrial and Labor Relations Review 57:2 (2004): 223 248.

[8] Card, D. "Using regional variation in wages to measure the effects of the federal minimum wage." Industrial and Labor Relations Review 46:1 (1992): 22-37.

[9] Card, D. "Do minimum wages reduce employment? A case study of California, 1987-89." Industrial and Labor Relations Review 46:1 (1992): 38-54.

[10] Dube, A., T. W. Lester, and M. Reich. "Minimum wage effects across state borders: Estimates using contiguous counties." The Review of Economics and Statistics 92:4 (2010): 945-964.

[11] Allegretto, S. A., A. Dube, and M. Reich. "Do minimum wages really reduce teen employment? Accounting for heterogeneity and selectivity in state panel data." Industrial Relations 50:2 (2011): 205-240.

[12] Kalenkoski, C. M., and D. J. Lacombe. "Minimum wages and teen employment: A spatial panel approach." Papers in Regional Science 92:2 (2013): 407-417.

[13] Schiller, B. R. "State minimum wage laws: Youth coverage and impact." Journal of Labor Research 15:4 (1994): 317-329.

\section{Online extras}

The full reference list for this article is available from:

http://wol.iza.org/articles/effects-of-minimum-wages-on-youth-employment-and-income

View the evidence map for this article:

http://wol.iza.org/articles/effects-of-minimum-wages-on-youth-employment-and-income/ map 